\title{
Implementation of the Polar Code: Functional Requirements Regulating Ship Operations in Polar Waters
}

\author{
Espen Engtrø ${ }^{1}$, Ove Tobias Gudmestad ${ }^{2}$ and Ove $\mathrm{Njå}^{1}$ \\ ${ }^{1}$ Faculty of Science and Technology, Department of Safety, Economics and Planning, \\ University of Stavanger, Norway; ${ }^{2}$ Faculty of Science and Technology, Department of \\ Mechanical and Structural Engineering and Materials Science, University of Stavanger, \\ Norway
}

\begin{abstract}
In 2017, the The International Code for Ships Operating in Polar Waters (Polar Code) - a set of function-based regulations applicable to Arctic and Antarctic waters, with the goal of increasing awareness and improving safety for ship operations in polar waters - entered into force. This article examines the Polar Code's contribution to the establishment of new standards and guidelines, with the problem under discussion being the extent to which the function-based regulations contribute to enhancing safety for ship operations in the Arctic, given that maritime activities in these waters are associated with great risks and uncertainties. The article gives a historical review, elucidating the background leading to the development of the Polar Code, followed by a review of the structure and key principles of the regulations. Further, ship traffic in the Arctic region and those subject to the Polar Code are examined, followed by a summary of findings and experiences from three survival exercises (SARex I, II and III), performed in northern areas around Svalbard between 2016 and 2018. The article concludes that safe ship operations depend on those subject to the regulations conducting thorough operational risk assessments that cover all potential hazards, in order to mitigate sufficiently. Further, the presence of authorities is found to be crucial, with validation of the adequacy and the dimensioning of the implemented measures being of the essence.
\end{abstract}

Keywords: Arctic shipping; risk management; emergency response; regulatory governance Responsible Editor: Øyvind Ravna, Faculty of Law, UiT The Arctic University of Norway, Tromsø, Norway

Received: March 2020; Accepted: June 2020; Published: August 2020

\footnotetext{
^Correspondence to: Espen Engtrø, email: espen.engtro@uis.no

(C) 2020 Espen Engtrø, Ove Tobias Gudmestad \& Ove Njå. This is an Open Access article distributed under the terms of the Creative Commons Attribution-NonCommercial 4.0 International License (https://creativecommons.org/licenses/by$\mathrm{nc} / 4.0 /$ ), allowing third parties to share their work (copy, distribute, transmit) and to adapt it, under the condition that the authors are given credit, that the work is not used for commercial purposes, and that in the event of reuse or distribution, the terms of this license are made clear.

Citation: Espen Engtrø, Ove Tobias Gudmestad E Ove Njå. "Implementation of the Polar Code: Functional Requirements Regulating Ship Operations in PolarWaters" Arctic Review on Law and Politics, Vol. 11, 2020, pp. 47-69. http://dx. doi.org/10.23865/arctic. 111.2240
} 


\section{Introduction}

The International Code for Ships Operating in PolarWaters (Polar Code) came into force on 1 January 2017, to increase awareness and improve safety for ship operations in polar waters, covering both the Arctic and the Antarctic. ${ }^{1}$ The function-based regulations constitute a continuation of existing regulations, made mandatory under the International Convention for the Safety of Life at Sea (SOLAS) and the International Convention for the Prevention of Pollution from Ships (MARPOL), applicable to all waters. The goals for implementing the Polar Code are "to provide for safe ship operation and the protection of the polar environment by addressing risks present in polar waters and not adequately mitigated by other instruments of the Organization". ${ }^{2}$ The problem discussed in this article is the extent to which the function-based regulations contribute to enhancing the safety of ship operations in the Arctic, given that maritime activities in these waters are associated with great risks and uncertainties. The Polar Code's risk-based approach to determining the scope of ship operations and its holistic approach to reducing identified risks ${ }^{3}$ implies industry self-regulation as its main principle. We argue that self-regulation demands strong professional integrity and high levels of competence, both from those subject to the regulations and the authorities, and from the recognized classification societies issuing the Polar Ship Certificate. The topic addressed is risk regulation at the international and governing levels, with complex issues handled by a variety of industries and involved parties; our main concern is the capability to handle major emergency situations in cold climate areas. ${ }^{4}$

The article examines the processes which led to the Polar Code before evaluating implementation and enforcement of the regulations. It starts with a historical review that elucidates the work leading to the Polar Code. A review of the structure and key principles of the regulations follows. Then ship traffic in the Arctic region and those subject to the regulations are examined. This is followed by a summary of experiences and lessons learned from three Arctic search and rescue (SAR) exercises. ${ }^{5}$ Then we discuss new guidelines under development for ship operations in the Arctic Region in the wake of the Polar Code. Finally, a systematic collection of data on related matters has been carried out, enabling us to evaluate how practices are evolving.

The issues raised in this article were first addressed by the authors in a paper published in Norwegian; ${ }^{6}$ however, the text has been expanded considerably and updated with information about the implementation of regulations since 2018.

\section{The Polar Code's historical development}

In 1989, the oil tanker, Exxon Valdez, ran aground near the coast of Alaska, becoming one of history's largest environmental disasters. ${ }^{7}$ The accident subsequently raised public awareness, and an international process was initiated, in which several 
countries strove to establish and agree upon international regulations and guidelines for ship traffic in polar waters. ${ }^{8}$ Maritime activity in these waters was regulated by international laws and the laws of coastal states with territorial sovereignty, which could be contradictory. ${ }^{9}$ Despite the additional challenges represented for ships operating in polar areas, many operators did not consider the added risks associated with cold climate operation. ${ }^{10}$

In 1991, IMO received a proposal from its member state Germany to include rules in SOLAS regarding ice strength for ships intended for polar voyages, in accordance with the rules of a recognized classification society. ${ }^{11}$ The Maritime Safety Committee in IMO relayed the proposal to the subcommittee for Ship Design and Equipment, which handed the work to an informal external working group, to develop proposed guidance regarding technical concerns for ships operating in polar waters. ${ }^{12}$ This group, led by Canada, worked according to certain key strategies: ${ }^{13}$ the guidelines should be based on existing IMO regulations and standards for safety, environmental protection and training; an equal focus should be placed on safety for human life and environmental considerations; the United Nations Convention on the Law of the Sea (UNCLOS) for polar waters should be used as legal framework; and competence and knowledge from Russia, Canada and the Baltic states on ice navigation and regulatory regimes should be taken into consideration.

In 1998, the subcommittee for Ship Design and Equipment received a draft of the International Code of Safety for Ships in Polar Waters, but changes to the draft were made after submissions from several states and interest groups. Among other issues, the Antarctic was removed as a geographical area, and any contradictions to international laws were removed. ${ }^{14} \mathrm{~A}$ new revision, Guidelines for Ships Operating in Arctic Polar Waters, was drafted and, after minor modifications, approved in 2002, named the Guidelines for Ships Operating in Arctic Ice-covered Waters. These recommended guidelines were amendments to the SOLAS convention but not made mandatory. ${ }^{15}$ During the next two years, ship traffic increased around the South Pole, and the Antarctic Treaty Consultative Meeting requested that IMO amend the Guidelines for Ships Operating in Arctic Ice-covered Waters to be applicable to the ice-covered waters around the Antarctic. ${ }^{16}$

In 2007, the cruise ship, MV Explorer, hit the underwater part of an iceberg and eventually sank off the South Shetland Islands in the Antarctic with 100 passengers and a crew of 54, all rescued. ${ }^{17}$ The accident placed further focus on establishing joint guidelines, applicable to the Arctic and the Antarctic, ${ }^{18}$ and, in 2009, IMO approved the Guidelines for Ships Operating in Polar Waters. The United States, Norway and Denmark argued that requirements should be mandatory, and a process was initiated to finalize the guidelines by 2012, but disagreements amongst nations and interest groups contributed to a postponement of the implementation date. ${ }^{19}$ It was particularly difficult to reach a consensus on certain requirements regarding environmental protection. ${ }^{20}$ In 2012, IMO postponed the work, as agreements addressing environmental requirements were not reached. ${ }^{21} \mathrm{IMO}$ and certain 
member states of the Arctic Council were criticized for being reactive in the development and implementation of the new guidelines, and the shipping and shipbuilding industries were accused of showing a lack of support for adhering to the provisions in the guidelines, possibly due to infrastructure and technological constraints. ${ }^{22}$ However, in 2014, draft guidelines were finalized, and produced as amendments to the SOLAS convention. The following year the guidelines were created as amendments to the MARPOL convention. ${ }^{23}$ Finally, in 2017, the Polar Code came into force.

\section{Structure and key principles of the Polar Code}

The Polar Code consists of two parts: Part I contains provisions on safety measures, made mandatory under the SOLAS convention; Part II contains provisions on measures to prevent pollution, made mandatory under the MARPOL convention. Furthermore, Parts I and II are divided into two parts, with part one (I-A) being mandatory and part two (I-B) consisting of guidelines and recommendations to the mandatory provisions. In the following, provisions on safety measures (Part I) are examined; these apply to passenger ships carrying more than twelve passengers or cargo ships with a gross tonnage of 500 or more, engaged in international voyages. ${ }^{24}$ The requirements in the Polar Code are mainly function-based, meaning they are related to risk factors in operating areas, such as ice conditions and temperatures. ${ }^{25}$ Shipowners must therefore carry out operational risk assessments of areas of operation, which, together with operational capabilities and limitations, shall be documented in the ship's Polar Water Operation Manual (PWOM), to be carried on board the vessel. ${ }^{26}$ The PWOM shall include or refer to procedures to be followed in normal operations and in order to avoid encountering conditions exceeding the ship's capabilities. The PWOM shall also contain specific procedures to be followed in the event of an incident, if conditions are encountered which exceed the ship's specific capabilities and limitations, in addition to procedures for icebreaker assistance. ${ }^{27}$

Under the safety measures (Part I) of the Polar Code, ten references are made to standards and guidelines for ice types, ship structure, machinery installations, voyage-planning and operational assessments. The guidelines for operational assessments are based on a mechanistic risk analysis process; estimated risk values are compared with risk acceptance criteria, to optimize solutions. As no guidelines have been issued for cold climate, the analytical techniques must be adapted to the environmental conditions. The prescriptive standards for construction referred to in the regulations were developed over time, based on empirical models aligned with regular norms for construction (load, structural response and safety margins). These standards and guidelines have not been modified since the application of the Polar Code, although "Requirements regarding Polar Class", sections I1 and I2, were revised in 2016 . 


\subsection{Goal-based standards}

A goal-based standards approach was used in the development of the Polar Code, ${ }^{28}$ regarding the design and construction of ships and equipment, operational conditions and training, and protection of the environment. ${ }^{29}$ Goal-based standards comprise at least one goal, functional requirement(s) associated with that goal, and regulation(s) which meet the functional requirement(s), including the goal..$^{30}$ The goal-based standards approach is seen in the following chapters of the Polar Code: PWOM (Ch. 2), ship structure (Ch. 3), subdivision and stability (Ch. 4), watertight and weather-tight integrity (Ch. 5), machinery installations (Ch. 6), fire safety/protection (Ch. 7), lifesaving appliances and arrangements (Ch. 8), safety of navigation (Ch. 9), communication (Ch. 10), voyage planning (Ch. 11), manning and training (Ch. 12).

As an example, the goal-based standards approach for life-saving appliances and arrangements is "to provide for safe escape, evacuation and survival", ${ }^{31}$ where the functional requirement for evacuation is that "All life-saving appliances and associated equipment shall provide safe evacuation and be functional under the possible adverse environmental conditions during the maximum expected time of rescue". ${ }^{32}$ One regulation for evacuation states that "Ships shall have means to ensure safe evacuation of persons, including safe deployment of survival equipment, when operating in ice-covered waters, or directly onto the ice, as applicable". ${ }^{33}$ The functional goals in the Polar Code facilitate interpretations and discretionary assessments, and those subject to the regulations must gain insight into significant environmental loads and structural responses, requiring an extensive systemic understanding.

Although the requirements in the Polar Code are distinctly functional, descriptive guidelines for the analytical processes are provided. The regulations use precise definitions, in addition to definitions referred to in SOLAS and MARPOL, which are not rendered in the Polar Code. Those subject to the regulations must therefore be familiar with the existing IMO regulations. The Polar Code specifies several explicit sources of hazards, such as icing, low temperatures and remoteness, ${ }^{34}$ guiding the analytical approach. The definitions habitable environment, maximum expected time of rescue and Mean Daily Low Temperature (MDLT) are significant for design and solutions and are determinative in the dimensioning processes. The most concrete and descriptive requirement concerns time of rescue, where "Maximum expected time of rescue means the time adopted for the design of equipment and system that provide survival support. It shall never be less than 5 days". ${ }^{35}$

\subsection{Polar Ship Certificate}

New ships constructed after the introduction of the Polar Code (1 January 2017), entitled to operate in the application area of the regulations, are required to obtain a valid Polar Ship Certificate. Ships constructed before that date, operating in the same areas, are required to obtain the Polar Ship Certificate by the first intermediate or renewal survey, whichever occurs first, after 1 January 2018. ${ }^{36}$ The Norwegian 
Maritime Authority (NMA) issues the Polar Ship Certificate for ships flagged by the Norwegian Ordinary Ship Register. The issue of certificates for ships in the Norwegian International Ship Register is delegated to recognized classification societies on behalf of the flag state the ship is registered under. ${ }^{37}$

The Polar Code's geographical area of application in the Arctic is shown in Figure 1 below. In the Antarctic, the regulations are applicable at the 60th parallel south. Different industries and parties with activities in these waters are subject to the Polar Code's requirements.

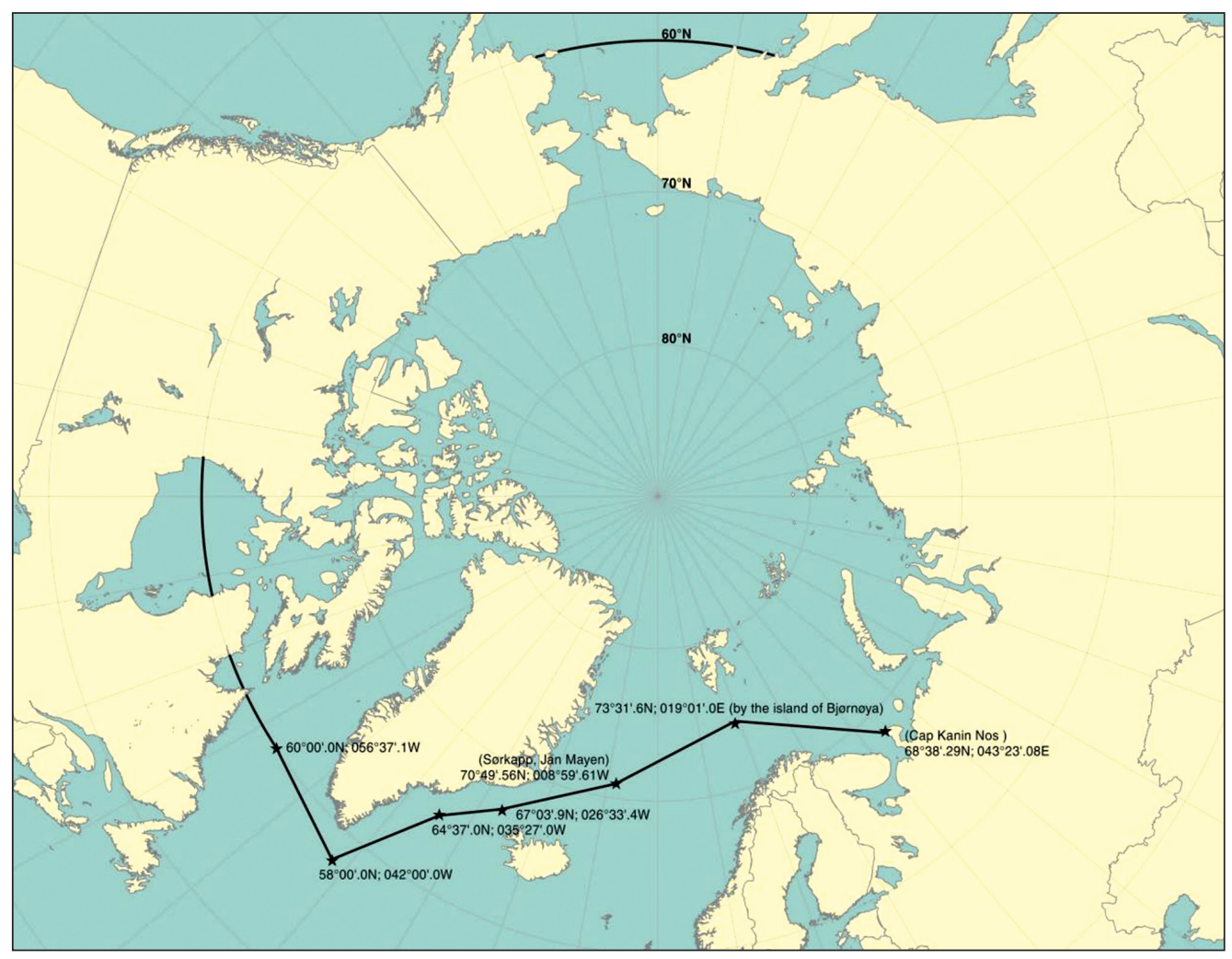

Figure 1. Maximum geographical extent of the Polar Code's area of application in the Arctic. ${ }^{38}$

\section{Ship traffic in the Arctic Region}

The receding sea ice in the Arctic is enabling an increase in shipping across the northern polar region, connecting Asia and Europe by trans-Arctic routes along (Figure 2): the Northeast Passage (NEP) and the Northern Sea Route (NSR), encompassing the route along the Norwegian and Russian Arctic coasts; the North West Passage (NWP), which follows Canada's northern coastline; and the Transpolar Sea Route (TSR), which bisects the Arctic Ocean through the North Pole. ${ }^{39}$ In 
addition, the Arctic Bridge Route (ABR), a shipping route linking the Arctic seaports of Murmansk (Russia) and Churchill (Canada), could develop into a future trade route between Europe and Asia. ${ }^{40}$

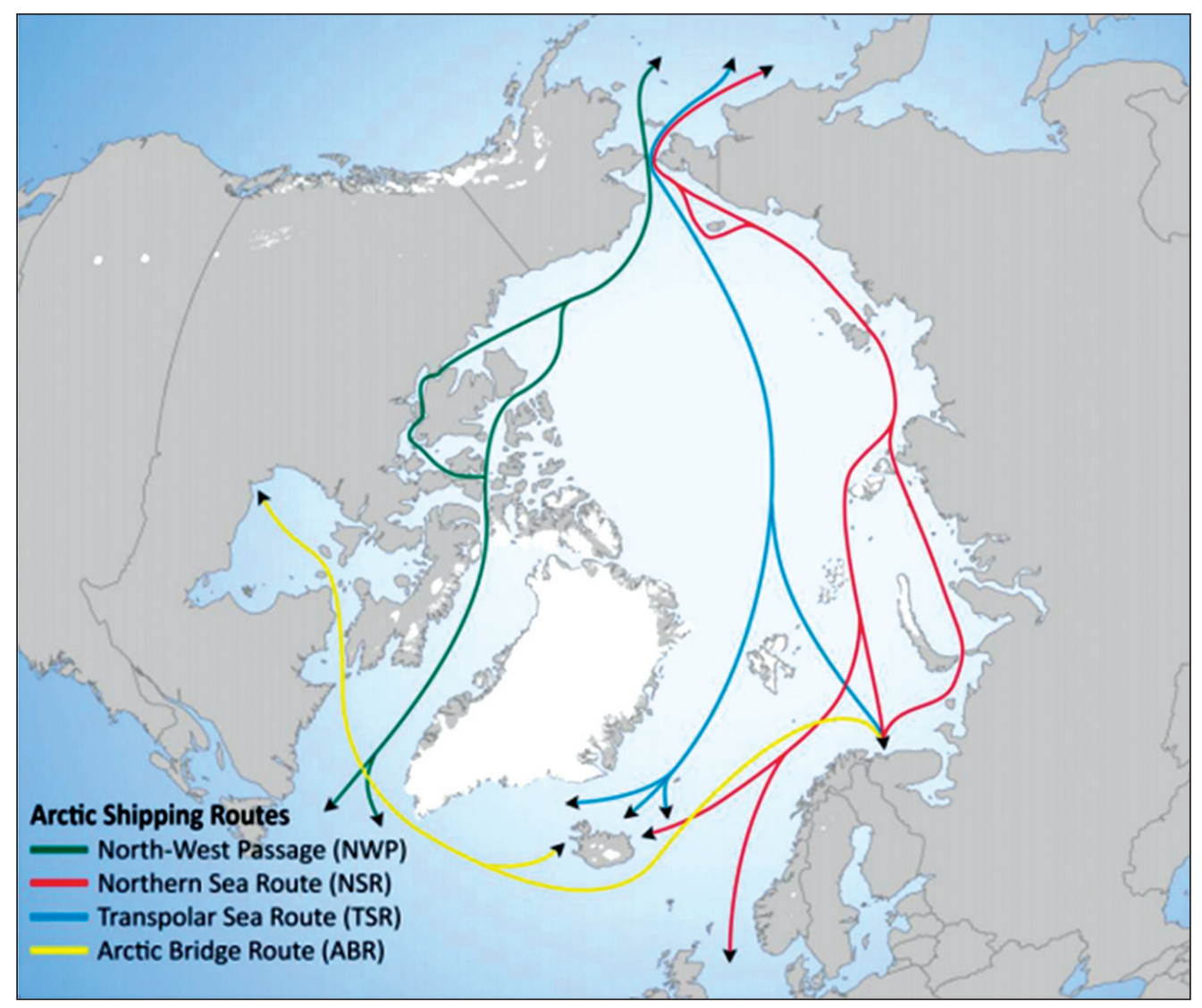

Figure 2. Shipping routes in the Arctic Region. ${ }^{41}$

Ship traffic can be divided into four main categories: ${ }^{42}$

1. Oil tankers or Liquefied Natural Gas (LNG) tankers/condensate tankers and tankers for refrigerated gas

2. Transport ships (with cargo other than oil or gas)

3. Passenger ships (including cruise ships)

4. Fishing vessels.

Measurements of the volume of shipping within the Polar Code's geographical area of application in the Arctic, taken between 2013 and 2019, show a substantial increase in traffic, when counting both the number of individual ships (up 25 percent) and the total nautical distance sailed during the six-year period in the same area (up 
75 percent). ${ }^{43}$ Fishing vessels dominate both groups, representing more than 40 percent of all ships in the Arctic area, and, of the total distance sailed, fishing vessels account for 45 percent. ${ }^{44}$ However, fishing vessels are neither subject to the SOLAS Convention nor any other international safety regulations. In 1977, IMO approved the Torremolinos International Convention ${ }^{45}$ but has yet to succeed in achieving ratification of the protocol by enough states with large numbers of fishing vessels. ${ }^{46} \mathrm{In}$ addition to fishing vessels, cargo ships of less than 500 gross tonnage, ships not propelled by mechanical means, wooden ships of primitive build, and pleasure yachts not engaged in trade are exempt from the safety provisions of the Polar Code (Part I) ${ }^{47}$

An increase in passenger-ship traffic in the northern areas is expected, especially due to reduced sea ice enabling ship traffic in open waters between the Atlantic and the Pacific Oceans during short periods of the year. ${ }^{48}$ In 2016 and 2017, the passenger ship, Crystal Serenity, sailed through the NWP from Alaska to New York, with more than 1,000 passengers, on its first voyage. ${ }^{49}$ The cruise industry is profitdriven and, to remain commercially competitive, costs related to safety equipment are often kept to a minimum. ${ }^{50}$ The shipbuilding industry delivering polar expedition vessels for the Arctic is peaking, with 28 new builds expected to be launched in the four-year period from 2018 to 2022 . This is in addition to the almost 80 polar ships already operating with passengers in these waters. ${ }^{51}$ Moreover, the extraction of natural resources in the Arctic is expanding and contributing to an increase in bulk carrier traffic in the region..$^{52}$

\section{SARex I, II \& III - Studies of the Polar Code and emergency response in polar waters}

The Norwegian Coast Guard, together with the University of Stavanger (UiS) and the University of Tromsø (UiT), have taken great interest in the conditions for SAR and evacuation operations in Arctic waters. In the SARex I, II \& III exercises, performed in 2016, 2017 and 2018, respectively, the Coast Guard played a key role in the work of testing emergency response equipment with respect to requirements for survival, as set out in the Polar Code. In these exercises, the Polar Code was used as a baseline for studying emergency response equipment and personal capabilities for survival in real-event situations. ${ }^{53}$ Each exercise lasted for a week and was conducted from the Coast Guard ship, KV Svalbard, in northern areas around Svalbard. In joint collaborations, requirements in the regulations were used as criteria for survival and were examined and tested against SOLAS-certified life-saving appliances, approved for Arctic waters. ${ }^{54}$ Regarding performance standards, the Polar Code states that "Unless expressly provided otherwise, ship systems and equipment addressed in this code shall satisfy at least the same performance standards referred to in SOLAS". ${ }^{55}$ The SOLAS Convention's mandatory requirements for merchant ships therefore constitute a standardized minimum of expectations for the provision of safety measures for maritime design, equipment, systems and operations. 


\subsection{SARex I}

The objectives of the first SAR exercise were to identify and explore gaps between the functionality of existing SOLAS-certified life-saving appliances and functional requirements in the Polar Code. ${ }^{56}$ The exercise was a joint collaboration between the Coast Guard, leading experts from the industry, governmental organizations and academia. The exercise scenario, which took place in the marginal ice zone off the coast of Svalbard in late April 2016, was based on the Maxim Gorkiy accident in 1989, where an expedition cruise ship hit drifting ice and partly sank in the marginal ice zone off the west coast of Svalbard. ${ }^{57}$ Focusing especially on the interpretation of the Polar Code's requirements for life-saving appliances and arrangements, the following definition was established: "The equipment required by the Polar Code is to provide functionality that enables the casualty to safeguard individual safety, which means to maintain cognitive abilities, body control and fine motor skills for the maximum expected time of rescue"..$^{58}$

The objectives of the exercise and the associated research program were to: ${ }^{59}$

- Assess the adequacy of the life-saving appliances as required by the Polar Code.

- Identify the gaps between SOLAS-approved rescue craft (lifeboat and life raft) and requirements defined in the Polar Code.

- Identify the gaps between SOLAS-approved personal protective equipment (PPE) and the requirements defined in the Polar Code.

- Assess the personal (PSK) and group survival kits (GSK) as defined by the Polar Code.

- Train the Coast Guard personnel in emergency procedures in ice-infested waters, with particular reference to evacuation and rescue from cruise ships.

One lifeboat and one life raft were filled with participants. Various types of standardized SOLAS-certified PPE were worn, ranging from life jackets to insulated survival suits. The weather conditions during the exercise were representative of the cruise-ship season around Svalbard, with an ambient air temperature of about $-9^{\circ} \mathrm{C}$, a water temperature of about $-1{ }^{\circ} \mathrm{C}$, little wind and no clouds. The results from the exercise concluded that it would be unlikely that the majority of participants evacuated (to lifeboat or life raft) would have survived for a minimum of five days, as the Polar Code requires. ${ }^{60}$ Critical conditions occurred, as insulation from the cold sea water provided by the bottom of the life raft was negligible, and the temperature in the lifeboat dropped dramatically when engines were shut down to save fuel. As $\mathrm{O}_{2}$ concentrations dropped inside the lifeboat and life raft, frequent venting had to be maintained, lowering the air temperature inside both craft. The SARex I experiment demonstrated that, when tested in Arctic waters, standard SOLAS-certified life-saving appliances do not comply with functional requirements in the regulations. ${ }^{61}$ 


\subsection{SARex II}

The second SAR exercise was performed in Krossfjorden, North Svalbard, in May 2017. The objective of SARex II was to test whether small investments in modifications and upgrades to life-saving appliances would be sufficient, when tested in the same environmental climate and conditions. ${ }^{62}$ The participants wore SOLAScertified PPE of various standards. The ambient air temperature varied between $+2^{\circ} \mathrm{C}$ and $-9^{\circ} \mathrm{C}$, while the water temperature was about $+2^{\circ} \mathrm{C}$. The following modifications to the lifeboat and life raft had been performed: ${ }^{63}$

- Upgraded heating system in lifeboat, maintaining the temperature inside the craft at a reasonable level.

- Insulated seating in lifeboat, protecting from hypothermia.

- Toilet installed in lifeboat (compact carry-on design).

- Double-bottom life raft, improving insulation and ensuring an air gap to be maintained between seawater and floor.

- Double-layer roof in life raft, providing insulation from cold outside air temperatures.

The results from SARex II were encouraging and significant, compared to the results from the previous exercise in 2016. Nevertheless, life-saving appliances did not meet the Polar Code's goal and requirement to provide the capability for people to survive for five days. ${ }^{64}$ The main critical issue in the lifeboat was the buildup of $\mathrm{CO}_{2}$ from the participants, even though the number of Personnel On Board (POB) during the exercise was lower than SOLAS requirements. ${ }^{65}$ Air quality was continuously monitored in both rescue craft. After approximately one day, all participants had been evacuated from the lifeboat, many exhausted due to lack of comfortable seating, minimal room for movement and insufficient emergency food rations and water. After 33 hours, the remaining participants in the life raft were evacuated, experiencing hypothermia and fatigue. ${ }^{66}$ Following the exercises, the recommendations from the emergency management team were to conduct a thorough evaluation, compare the results with the Polar Code's requirements and identify gaps to be closed, partly or fully ${ }^{67}$

\subsection{SARex III}

In May 2018, the third SAR exercise was performed in Fjortende Julibukta, north of Ny-Ålesund, Svalbard. SARex III had three main objectives: ${ }^{68}$

1. Study functionality and identify gaps between typical PSK and GSK, regarding survival on ice/land, and the requirement of a minimum of five days' survival.

2. Study the challenges when rescuing many people from land/ice.

3. Assess the functionality of utilizing Maritime Broadband Radios (MBR) to develop an improved common operational picture among the different emergency response providers. 
The weather conditions during the exercise were favorable, with very little wind, some snow and rain showers during the first two days and temperatures varying from a maximum of $3^{\circ} \mathrm{C}$ to a minimum of $-3^{\circ} \mathrm{C}$ at night. ${ }^{69}$ The first objective of the exercise proved to be an impossible task, due to great variations in the activity levels of the individual participants during the exercise, to compensate for heat loss. However, compared with findings from SARex I and SARex II, it became evident that there was a significant improvement in the survival rate when evacuating onto the shore, compared with a prolonged stay in the survival craft. One important finding was, furthermore, that the rations contained insufficient water for healthy survival. ${ }^{70}$ To assess the second objective, about 50 "casualties" were evacuated from a remote beach onto the ship, Polarsyssel, revealing the additional challenges of managing many casualties with regard to time, which is a critical element in a survival situation in a cold climate. ${ }^{71}$ Regarding the third objective, the MBR system proved reliable, but significant technical expertise was needed to initiate it. ${ }^{72}$

\section{The Polar Code footprints}

At the time of writing (June 2020), the Polar Code has been in force for more than three years, and the effects of its implementation are starting to appear. The regulation of ship operations in polar areas is determined by geographical and seasonal variation, which guide the choice of safety measures, equipment and systems provided. ${ }^{73}$ Those subject to the Polar Code form a group, consisting of different parties ${ }^{74}$ amongst whom the owner of an oil or gas tanker does not necessarily share the same risk perceptions as the owner of a cruise ship with the capacity to transport several hundred passengers on a single voyage. Due to the Polar Code's functionally based approach, compliance with the regulations can be achieved using various methods and measures. The SAR exercises, with the objective of exploring gaps between SOLAS-certified life-saving appliances and arrangements, and the Polar Code's requirements for such equipment, proved that ships on polar voyages are likely to be equipped with insufficient survival equipment and resources. ${ }^{75}$

\subsection{Interim guidelines for life-saving appliances and arrangements for ships operating in polar waters}

The findings from the three SAR exercises raise concerns regarding the suitability and efficiency of equipment provided in an emergency that requires a ship to be abandoned. ${ }^{76}$ Less than two years after the Polar Code was implemented, the Maritime Safety Committee in IMO approved (June 2019) The interim guidelines on life-saving appliances and arrangements for ships operating in polar waters. ${ }^{77}$ The results of the SAR exercises and the discussions that arose after these events contributed to the development of the new guidelines, ${ }^{78}$ providing guidance and outlining possible means of mitigating hazards, in order to comply with the requirements as set out in the Polar Code for life-saving appliances and arrangements. ${ }^{79}$ The guidelines provide descriptive 
guidance for food ( $\min .1195 \mathrm{kcal}$ per person per day) and water (min. 2 liters per person per day), and (the prevention of long-term) exposure to $\mathrm{CO}_{2}$ concentrations $(>5,000 \mathrm{ppm})$, for the maximum expected time of rescue. Guidelines for maintaining a positive metacentric height (GM), with additional ice loads $\left(30 \mathrm{~kg} / \mathrm{m}^{2}\right.$ on exposed horizontal surfaces and $7.5 \mathrm{~kg} / \mathrm{m}^{2}$ for the projected lateral area of each side of the lifeboat), are given for lifeboats and rescue boats, in addition to guidance and descriptions of the survival craft's capacity, equipment and winterization measures deemed necessary for cold climate voyages and survival. The guidelines also provide specifications on survival suits, protective clothing and other survival equipment, including guidance regarding the packing, storage and marking of such equipment. ${ }^{80}$

\subsection{Regulations on the construction, equipment and operation of passenger ships in the territorial waters surrounding Svalbard}

In (June) 2019, the NMA laid down new Regulations on the construction, equipment and operation of passenger ships in the territorial waters surrounding Svalbard, ${ }^{81}$ which came into force on 1 January 2020. With a few exceptions and additions, the regulations are the Polar Code, made applicable for passenger ships operating in the territorial waters surrounding Svalbard. ${ }^{82}$ Until this point, ships with national certificates had been subject not to the safety provisions (Part I) of the Polar Code, but to MARPOL and national requirements for the certificates required to operate passenger ships in Svalbard. ${ }^{83}$ The Polar Code's safety provision applies, per definition, only to passenger ships (carrying more than twelve passengers) or cargo ships (with a gross tonnage of 500 or more) engaged in international voyages ${ }^{84}$ where an "international voyage means a voyage from a country to which the present Convention applies to a port outside such country, or conversely". ${ }^{55}$ Under the new regulations, passenger ships operating in the territorial waters surrounding Svalbard and passenger ships engaged in international voyages calling at Svalbard fall under the scope of the regulations. The NMA points out that "Due to Svalbard's judicial position, ${ }^{86}$ it is important to have equal rules for all flag States, predictability and clear legislation for ships carrying passengers in the territorial waters surrounding Svalbard". ${ }^{87}$

The NMA states ${ }^{88}$ that implementing the new regulations means that future development of the legislation in Svalbard will take place in line with new legislation being negotiated internationally in IMO, which is an advantage point for the NMA, which also regulates ships flying foreign flags. In a circular, ${ }^{89}$ the NMA acknowledges the processes within IMO leading to the development and implementation of new conventions, regulations and guidelines or changes and updates of existing ones. These processes are described as open and balanced, safeguarded by the opportunity for different interests to put forward their views before the member states lay down new provisions or change existing ones..$^{90}$

In the comments on the individual sections, ${ }^{91}$ reference is made to the abovementioned SAR exercises and recommendations from these events, which, supported by Canadian research (Transport Canada), guide the choice of life rafts, 
requiring these to be of a type with an inflatable double bottom. In the same circular, the NMA points out the systematics applicable for the regulation of life-saving appliances; "Performance requirements shall be supported by test or evaluation requirements in resolution Revised recommendation on testing of life-saving appliances" ${ }^{92}$ But, due to the lack of test requirements describing the insulation properties of the raft floor, there are no parameters with which to measure equivalence. The NMA therefore decided "to lay down a requirement for an inflatable floor while waiting for the IMO to introduce a test standard that will ensure equivalence by establishing measurable requirements for insulation properties/heat loss". ${ }^{93}$

\subsection{The Arctic Shipping Best Practice Information Forum}

In response to the Polar Code's implementation, the Arctic Council's working group, Protection of the Arctic Marine Environment (PAME), launched a public web portal in 2018: The Arctic Shipping Best Practice Information Forum ${ }^{94}$ The forum's collaborative approach aims to support education, as regards implementation of the regulations, and to raise awareness of the Polar Code's provisions amongst parties involved in or potentially affected by Arctic maritime operations..$^{95}$ The goal is to facilitate the exchange of information and best practices on specific topics, e.g. hydrography, search and rescue logistics, industry guidelines and ship equipment, systems and structure. ${ }^{96}$ Stakeholder involvement in the forum has increased since start-up and includes individual governments, regional governmental bodies (Arctic Council/Antarctic Treaty Secretariat), international regulators (IMO), the research community, the maritime industry, the indigenous community, educational institutions and other Arctic Council Working Groups. ${ }^{97}$ The web portal, provides submissions by some of the above-mentioned stakeholders, following the chapters of the Polar Code, with hyperlinks to the SAR exercises, Arctic member states' guidance on Arctic operations, and classification societies' guidance and information regarding implementation and operations in accordance with the regulations.

\section{Discussion - Standardization as part of regulatory governance}

The tendency to adopt a goal-based standards approach in regulatory governance is increasing ${ }^{98}$ with responsibility for developing definitive descriptive standards and guidelines being delegated from government officials to the actors and target groups that the regulations are intended to regulate. From a rational approach, functional requirements enable those subject to the regulations to choose flexible solutions best suited to their own business areas and activities. ${ }^{99}$ However, there is considerable heterogeneity among the actors subject to the Polar Code, and we predict challenges in enforcement of the regulations. A centralized and international process for standardization, equal to the International Association of Classification Societies (IACS) and the Polar Class requirements for ship structure, could provide predictability. Experience can be drawn from the Norwegian petroleum industry, with its extensive 
experience in utilizing functional requirements in the standardization of complex operations, supported by descriptive guidelines and detailed standards. ${ }^{100}$ The conditions and structures of the regulatory regime for ship operations in polar waters differ, however, from those of the petroleum industry; the Norwegian oil and gas industry consists largely of homogenous groups, and the power balance between employees, employers and the authorities has promoted safety-dominated practice. ${ }^{101}$

\subsection{Descriptive requirements and the protection of vulnerable parties' interests}

Established structures under IMO administration regulate the international shipping industry, in the form of recognized conventions, regulations and guidelines. ${ }^{102}$ The Polar Code contains a number of operational requirements and practical safety measures that apply to all types of ships, regardless of construction, design and trade area. The regulations were developed "to supplement existing IMO instruments in order to increase the safety of ships' operation and mitigate the impact on the people and environment in the remote, vulnerable and potentially harsh polar waters". ${ }^{103}$

During an emergency, the functionality of life-saving appliances and arrangements is vital. The Polar Code sets out requirements to ensure safe escape, evacuation and survival in the event of abandoning ship. ${ }^{104}$ The regulations also require individual and shared resources to be provided for effective protection against direct wind chill, to ensure sufficient thermal insulation to maintain core temperature, and protection to prevent frostbite of all extremities. ${ }^{105}$ However, the Polar Code guidelines for protective equipment $\mathrm{t}^{106}$ are vague and generic, and a variety of equipment available on the market is compliant, regardless of its usability under real conditions. ${ }^{107}$ The SAR exercises revealed that performance criteria for certified rescue equipment did not comply with the Polar Code's requirements for survival, which state that "Resources shall be provided to support survival following abandoning ship, whether to the water, to ice or to land, for the maximum expected time of rescue". ${ }^{108}$

In the event of an abandon-ship situation, a dry-shod evacuation to lifeboats, life rafts or onto ice or onshore is essential for survival in cold climates, and the risk of hypothermia, leading to frostbite and eventually death, if not mitigated, increases dramatically when wet. ${ }^{109}$ Maintaining thermic balance is essential for survival. It is determined by the body's heat loss versus heat production, and affected by cold, wet and windy climate, poor clothing, lack of shelter, low activity level, and insufficient food and water rations. ${ }^{110}$ The new guidelines for life-saving appliances and arrangements for ships operating in polar waters point out that "Survival after abandonment will rely on several factors, such as the types and combination of equipment, crew training and good leadership of each survival craft. The expected time of rescue is a defining factor for life-saving appliances and arrangements. Conditions that are not otherwise considered critical may become critical over time". ${ }^{111}$

The lack of specifications and guidelines clarifying Polar Code requirements for safe escape, evacuation and survival may contribute to the great variation seen in 
polar protective equipment. ${ }^{12}$ The new guidelines for life-saving appliances and arrangements put forward descriptive requirements and specifications for emergency equipment and systems that shipowners and operators must take into consideration in the planning of polar voyages. However, the use of descriptive requirements and a non-flexible framework can turn out to be counter-effective, if compliance is achieved in a mechanical manner, with just checks and controls of predefined measures. ${ }^{113}$

\subsection{Functional requirements and the use of operational risk assessments}

Utilizing a goal-based standards approach and functional requirements puts pressure on the authorities and the organizations recognized by IMO to issue the Polar Ship Certificate. We argue that high levels of competency are required in the assessment of implemented measures. One must bear in mind that achieving compliance with a certain requirement does not automatically ensure compliance with the overall goals in the associated regulation. Each company is responsible for conducting adequate operational risk assessments covering their own activities. ${ }^{114} \mathrm{~A}$ company can, however, deliberately mislead or inadvertently underestimate certain risks in their analyses, by predicting consequences as acceptable and/or probabilities as low as reasonably practicable. Certain actors may take advantage of and exploit the functional requirements set out in the Polar Code, which raises questions about the role of the authorities. ${ }^{115}$ Experience from comparable industries has shown that thorough re-verifications of conducted risk assessments rarely occur. ${ }^{116}$

Re-verification, not only of operational risk assessments but also of existing analytical tools, must be conducted to verify whether potential risks for maritime activities in polar waters are covered in the planning and execution of voyages. Analytical models quantifying risk levels should be questioned, due to the significant uncertainties that exist in analysts' risk perceptions of descriptive scenarios. ${ }^{117}$ Mechanisms for control and constraints, and a theoretical systemic approach ${ }^{118}$ when analyzing maritime traffic in polar waters, should gain increased focus. The use of descriptive and detail-oriented requirements should also be evaluated, especially when uncertainties about phenomena increase, e.g. geography, environmental conditions or SAR operations in remote areas with limited resources. The involvement of the authorities, by addressing responsibilities within the industry in a competent manner, is of the essence, to reduce and eliminate favorable conditions for disreputable parties. ${ }^{119}$ Previous experience from maritime disasters indicates a business sector in which the reputation of some members poses a challenge. ${ }^{120}$ Parallels can be drawn with the heavy vehicle transport industry, where research indicates that functional requirements are often stretched. ${ }^{121}$

\subsection{Defining norms within the IMO system}

Standardization processes within IMO involving government officials, relevant parties and interest organizations can be clarifying and provide predictability in the 
enforcement of the Polar Code. ${ }^{122}$ Scientific facts can, however, be overlooked in favor of political points of view, as visions and goals are agreed upon amongst different cultures, institutions and states with competing agendas and financial situations. ${ }^{123}$ Developing new regulations can be time-consuming work, and is only achieved through extensive cooperation, ${ }^{124}$ as exemplified by the time ( $>25$ years) it took to develop and agree on the Polar Code. The new guidelines for life-saving appliances and arrangements introduce design specifications and clarifications, many seen in correlation with findings from the above-mentioned SAR exercises. ${ }^{125}$ These guidelines "are intended to assist ship designers, ship-owners and ship operators, as well as the administrators, in the uniform implementation of the Polar Code". ${ }^{126}$

After the SAR exercises, it was suggested that a level of heat loss regarded as acceptable for the human body to maintain for the expected time to rescue and based on a predefined heat loss figure, should be defined, allowing equipment and combinations of equipment to be assessed in a transparent way. ${ }^{127}$ The new guidelines for life-saving appliances and arrangements recommend that manufacturers provide information on additional tests, including temperature ranges for which the equipment is intended, and that this information is included in ships' operating and maintenance manuals. ${ }^{128}$

Concerns have been raised regarding non-SOLAS vessels operating in the Arctic region, ${ }^{129}$ as the Polar Code's safety provisions (Part I) are not applicable to these vessels, and especially with respect to fishing vessels, since they constitute the largest overall shipping presence in Arctic waters. ${ }^{130}$ The Maritime Safety Committee and related sub-committees within IMO are currently looking at the application of the Polar Code to vessels not regulated by the SOLAS Convention. At the end of 2019 the IMO assembly meeting adopted a resolution on interim safety measures for vessels not certified under the SOLAS Convention operating in polar waters, which urges IMO member states to implement, voluntarily, the safety provisions (Part I) of the Polar Code for non-SOLAS vessels. ${ }^{131}$

The web portal, The Arctic Shipping Best Practice Information Forum, ${ }^{132}$ has the potential to become a meeting ground for those subject to the Polar Code, facilitating the exchange of information, experience and best shipping practices, and exemplifying how to formalize enhanced knowledge on regulating ship operations in the Arctic Region.

\section{Conclusion and summary}

The implementation of mandatory regulations for ship traffic in the oceans around the North Pole and the South Pole is a step in the right direction, to sustain and protect personnel, the environment and ecosystems in vulnerable and remote parts of the world. Nevertheless, several issues concerning the Polar Code are highlighted in this article. 
People have sailed in polar waters for hundreds of years, ${ }^{133}$ and there is outstanding knowledge and experience regarding risk management and the handling of hazards in these waters. ${ }^{134} \mathrm{But}$, as new risks and hazards emerge, knowledge, experience and the capacity to handle these become limited, with mass tourism in polar waters being the main activity of concern. ${ }^{135}$

Self-regulation is based on trust, ${ }^{136}$ and those subject to the regulations need to conduct thorough operational risk assessments that identify hazards, followed by the implementation of mitigating measures, to ensure the safe performance of ship operations. Experience from the Norwegian petroleum industry indicates that not all companies and parties pay sufficient attention to this responsibility. ${ }^{137}$ The role of the authorities can be demanding, and a high level of expertise, competence and knowledge must be acquired for assessment of company-related risks, which is essential in evaluations of adequacy and in the dimensioning of implemented measures. One concern that should be raised is practical enforcement of the Polar Code (verifications and audits) and the management of control mechanisms within the geographical area of application, to ensure compliance with the regulations. We assume that controls performed by the Port State and the classification societies are essential in this regime. The use of sanctions - fines and withdrawal of the Polar Ship Certificate - is a possible response to non-compliance, as well as, in extreme situations, the arrest of ships. ${ }^{138} \mathrm{~A}$ further study to identify the main parties involved in the regulation of polar ship operations in northern areas and the key elements in this control regime, would be enlightening.

The three SAR exercises proved that SOLAS-certified rescue equipment was not compliant with the Polar Code requirements for survival, necessitating a joint effort from the authorities and interest groups to develop provisions for the regulations, to ensure that life-saving appliances and arrangements meet an expected standard. The relatively swift establishment and implementation of the new guidelines on life-saving appliances and arrangements is a positive signal for future revision. Re-assessment of the Polar Code's requirements for survival and the maximum expected time of rescue should also be addressed, for which exemptions are made when implementing the Polar Code for passenger ships operating in the territorial waters surrounding Svalbard. ${ }^{139}$ The emergency preparedness regime in Svalbard indicates that, in many cases, assistance will be available in less than the maximum expected time of rescue, and, in our opinion, it is unreasonable to require ships that only operate in the most central areas in Svalbard, such as Isfjord, ${ }^{140}$ to hold equipment for five-day rescue.

Even if the minimum-number-of-days requirement is not applicable, the functional requirement, as set out by the Polar Code, i.e. that every ship must be equipped to ensure survival for the expected time of rescue, remains. In circulars and comments on the individual sections of the new regulations, ${ }^{141}$ the NMA stresses that the expected time of rescue may also exceed five days in Svalbard, particularly for ships with a large number of persons on board operating in the most remote parts of the 
archipelago. It is therefore expected that the companies "must be able to document the assessments underlying the chosen time of rescue". ${ }^{142}$

At the time of writing, it has not been possible to obtain risk analyses or assessments justifying the requirements for maximum expected time of rescue and survival in the case of an abandonment-of-ship situation, as set out in the Polar Code.

\section{NOTES}

1. International Code for Ships Operating in Polar Waters (Polar Code), International Maritime Organization (IMO), MEPC 68/21, London 2017.

2. Ibid., Introduction, 1 .

3. Ibid., Preamble, 7.

4. Knut Espen Solberg and Ove Tobias Gudmestad, SARex3: evacuation to shore, survival and rescue (Vol. no. 75, Stavanger: University of Stavanger, 2018); Natalya A. Marchenko et al., "Arctic Shipping and Risks: Emergency Categories and Response Capacities”, TransNav Vol. 12, No. 1 (2018) 107-114, DOI:10.12716/1001.12.01.12; Natalia Andreassen et al., "Emergency Management in Maritime Mass Rescue Operations: The Case of the High Arctic", Springer International Publishing AG (2018) 359-381, https://doi. org/10.1007/978-3-319-78425-0.

5. Knut Espen Solberg, Ove Tobias Gudmestad and Bjørn Odin Kvamme, SARex Spitzbergen: April 2016: exercise report: search and rescue exercise conducted off North Spitzbergen (Vol. no. 58, Stavanger: University of Stavanger, 2016); Knut Espen Solberg, Ove Tobias Gudmestad and Eivinn Skjærseth, SARex2: Surviving a maritime incident in cold climate conditions (Vol. no. 69, Stavanger: Universitetet i Stavanger, 2017); Solberg and Gudmestad, SARex3: evacuation to shore, survival and rescue.

6. Espen Engtrø, Ove Njå and Ove Tobias Gudmestad, "Polarkoden - funksjonsbasert forskriftsverk for polare farvann: hvordan kan standarder presentere gode nok løsninger?” [The Polar Code - function-based regulations for polar waters: The contribution of standards to safe and sufficient solutions?], In: Regulering og standardisering: perspektiver og praksis [Regulation and standardization: Perspectives and practice] (Universitetsforlaget - Scandinavian University Press, 2018), ISBN 9788215028934, s. 146-162.

7. Megan Gannon, Exxon Valdez 25th Anniversary: 5 Facts About the Historic Spill, (LiveScience, March 24, 2014), accessed April 14, 2020. https://www.livescience.com/44314-exxon-valdez-spill-anniversary-facts.html

8. Øystein Jensen, “The International Code for Ships Operating in Polar Waters: Finalization, Adoption and Law of the Sea Implications", Arctic Review on Law and Politics 7 (2016): 60-82. https://doi.org/10.17585/arctic.v7.236

9. Jiayu Bai "The Polar Code: The Emerging Rules of Arctic Shipping Governance", The International fournal of Marine and Coastal Law 30 (2015): 674-699. https://doi.org/10. $1163 / 15718085-12341376$

10. Knut Espen Solberg, "Implications caused by SARex on the implementation of the IMO polar code on survival at sea", IOP Conference Series: Materials Science and Engineering, Vol. 276(1) (2017).

11. Jensen, "The International Code for Ships Operating in Polar Waters: Finalization, Adoption and Law of the Sea Implications."

12. Ibid.

13. Lawson W. Brigham, "The Developing International Maritime Organization Polar Code", Akureyri, Iceland: Northern Research Forum, Arctic Yearbook (2014). 
14. Jensen, "The International Code for Ships Operating in Polar Waters: Finalization, Adoption and Law of the Sea Implications"; Vijay Sakhuja, "The Polar Code and Arctic Navigation", Strategic Analysis, Vol. 38, No. 6 (2014): 803-811. https://doi.org/10.1080/09700161. 2014.952943

15. Ibid.

16. Jensen, "The International Code for Ships Operating in PolarWaters: Finalization, Adoption and Law of the Sea Implications".

17. Mike Schuler, $M / V$ Explorer - Investigation into Sinking of An Eco-Cruise Ship, (gCaptain, 14 April 14 2009), accessed 14 April 2020. https:/gcaptain.com/investigation-sinking-mvexplorer/

18. Jensen, "The International Code for Ships Operating in Polar Waters: Finalization, Adoption and Law of the Sea Implications".

19. ibid; Sakhuja, "The Polar Code and Arctic Navigation".

20. Sakhuja, "The Polar Code and Arctic Navigation".

21. Ibid.

22. Ibid.

23. Bai, "The Polar Code: The Emerging Rules of Arctic Shipping Governance”, p. 679.

24. International Convention for the Safety of Life at Sea (SOLAS), IMO, 1974, and 1978 and 1988 Protocol relating thereto: 2000 and 2004 amendments.

25. Polar Code, IMO, Ch. 1.5.

26. Ibid., Ch. 2 .

27. Ibid., Ch. 2.

28. “Goal-based standards, What are goal-based standards?", IMO, accessed 14 April 2020. http://www.imo.org/en/OurWork/Safety/SafetyTopics/Pages/Goal-BasedStandards.aspx

29. Polar Code, IMO.

30. "Goal-based standards, What are goal-based standards?", IMO.

31. Polar Code, IMO, Ch. 8, Para. 8.1.

32. Ibid., Ch. 8, Para. 8.2.2.

33. Ibid., Ch. 8, Para. 8.3.2.

34. Ibid., Introduction, Ch. 3.

35. Ibid., Ch. 1, Para. 1.2.7.

36. Regulations on safety measures for ships operating in polar waters and amendments to Regulations on environmental safety, Norwegian Maritime Authorities (NMA), RSR 15-2016.

37. Ibid.

38. The figure extracted from the Polar Code is for illustrative purposes only (pp. 8-9). For exact coordinates, the regulation refers to SOLAS Chapter XIV/1.3.

39. Albert Buixadé Farré et al., "Commercial Arctic shipping through the Northeast Passage: routes, resources, governance, technology, and infrastructure", Polar Geography 37:4, 298324 (2014), DOI: 10.1080/1088937X.2014.965769; Samrat Ghosh and Christopher Rubly, "The emergence of Arctic shipping: issues, threats, costs, and risk-mitigating strategies of the Polar Code", Australian fournal of Maritime E Ocean Affairs (2015) 7:3, 171-182, DOI: 10.1080/18366503.2015.1093695.

40. Malte Humpert and Andreas Raspotnik, "The Future of Arctic Shipping Along the Transpolar Sea Route", Arctic Yearbook (2012).

41. Ibid.

42. Viggo Jean-Hansen, "Skipstrafikken i området Lofoten - Barentshavet" [The seatraffic in The Barents Sea], Kystverket - The Norwegian Coastal Administration, Oslo, 2003.

43. Protection of the Arctic Marine Environment (PAME), "The increase in Arctic Shipping 2013-2019", Arctic shipping status report (ASSR) \#131 March 2020.

44. Ibid. 


\section{Espen Engtrø, Ove Tobias Gudmestad E Ove Njå}

45. International Regulations for the Safety of Fishing Vessels, IMO, MSC 92/26/Add.2 Annex 25: London, 1977.

46. Gudrun Petursdottir, Olafur Hannibalsson and Jeremy M. M. Turner, "Safety at sea as an integral part of fisheries management", The Food and Agriculture Organization of the United Nations (FAO), Fisheries Circular No. 966 (2001), FIIT/C966 ISSN 0429-9329; “The Torremolinos International Convention for the Safety of Fishing Vessels", IMO, accessed 14 April 2020. http://www.imo.org/en/About/Conventions/ListOfConventions/Pages/The-Torremolinos-International-Convention-for-the-Safety-of-Fishing-Vessels.aspx

47. SOLAS, IMO.

48. Kjetil S Grønnestad, Cruisetrafikk gjennom Arktis [Cruise traffic through the Arctic], (BarentsWatch, 17 January 2017), accessed 14 April 2020. https://www.barentswatch.no/artikler/ cruisetrafikk-gjennom-arktis/

49. Ibid.

50. Solberg, "Implications caused by SARex on the implementation of the IMO polar code on survival at sea".

51. Thomas Nilsen, Arctic cruise ship boom, (The Barents Observer, 22 May 2018), accessed 14 April 2020. https://thebarentsobserver.com/en/travel/2018/05/arctic-cruise-ship-boom

52. PAME, "The increase in Arctic Shipping 2013-2019".

53. Solberg, Gudmestad and Kvamme, SARex Spitzbergen: April 2016: exercise report: search and rescue exercise conducted off North Spitzbergen; Solberg, Gudmestad and Skjærseth SARex2: Surviving a maritime incident in cold climate conditions; Solberg and Gudmestad, SARex3: evacuation to shore, survival and rescue.

54. Ibid.

55. Polar Code, IMO, Ch. 1.4.

56. Solberg, Gudmestad and Kvamme, SARex Spitzbergen: April 2016: exercise report: search and rescue exercise conducted off North Spitzbergen.

57. Sølve Tanke Hovden, Redningsdåden: om Maksim Gorkiy-havariet utenfor Svalbard $i 1989$ [The Rescue: about the Maksim Gorkiy-accident outside Spitsbergen in 1989], (Sandnes: Commentum Forlag, 2012].

58. Solberg Gudmestad and Kvamme, SARex Spitzbergen: April 2016: exercise report: search and rescue exercise conducted off North Spitzbergen, p. vi.

59. Ibid, p. iv.

60. Ibid.

61. Ibid., pp. 32-34.

62. Solberg Gudmestad and Skjærseth, SARex2: Surviving a maritime incident in cold climate conditions.

63. Ibid., pp. 20-22.

64. Ibid.

65. Ibid.

66. Ibid.

67. Ibid.

68. Solberg and Gudmestad, SARex3: evacuation to shore, survival and rescue.

69. Ibid.

70. Ibid.

71. Ibid.

72. Ibid., p. 4.

73. Polar Code, IMO, Introduction, Ch. 3.2.

74. PAME, "The increase in Arctic Shipping 2013-2019."

75. Solberg and Gudmestad, SARex3: evacuation to shore, survival and rescue. 
76. Solberg Gudmestad and Kvamme, SARex Spitzbergen: April 2016: exercise report: search and rescue exercise conducted off North Spitzbergen; Solberg Gudmestad and Skjærseth, SARex2: Surviving a maritime incident in cold climate conditions; Solberg and Gudmestad, SARex3: evacuation to shore, survival and rescue.

77. The interim guidelines for life-saving appliances and arrangements for ships operating in polar waters, IMO, MSC.1/Circ.1614 2019.

78. Regulations on the construction, equipment and operation of passenger ships in the territorial waters surrounding Svalbard, NMA, RSR 032019.

79. The interim guidelines for life-saving appliances and arrangements for ships operating in polar waters, IMO.

80. Ibid.

81. Regulations on the construction, equipment and operation of passenger ships in the territorial waters surrounding Svalbard, NMA.

82. Ibid., p. 2.

83. Information on certificates required to operate passenger ships at Svalbard, NMA, RSV 01 2017.

84. SOLAS, IMO.

85. Ibid., Part A: Application, definitions, etc., Regulation 2 (d).

86. Treaty between Norway, The United States of America, Denmark, France, Italy, Japan, the Netherlands, Great Britain and Ireland and the British overseas Dominions and Sweden concerning Spitsbergen, The Svalbard Treaty, signed in Paris 9 February 1920.

87. Regulations on the construction, equipment and operation of passenger ships in the territorial waters surrounding Svalbard, NMA, p. 2.

88. Ibid.

89. Ibid.

90. Ibid.

91. Ibid., Section 12, second paragraph, p. 11.

92. Revised recommendation on testing of life-saving appliances, IMO, Resolution MSC.81(70) 1988.

93. Regulations on the construction, equipment and operation of passenger ships in the territorial waters surrounding Svalbard, NMA, p. 11.

94. "The Arctic Shipping Best Practice Information Forum", PAME, accessed 20 October 2019. https://pame.is/arcticshippingforum\#part-ia-safety-measures

95. Ibid.

96. "Meeting of Arctic Council's Protection of the Arctic Marine Environment Working Group at the Admiral Nevelskoy Maritime State University, Vladivostok, Russia, 1-4 October 2018”, PAME, accessed 20 August 2019. https://pame.is/images/03_Projects/Forum/PDF/ Presentation_PAME_II_02.10.2018_Vladivostok.Russia.Michael_Kingston_and_Hjalti_ Hreinsson._Final_.pdf

97. Ibid.

98. Steven T. Maher et al., "Paradigm Shift in the Regulatory Application of Safety Management Systems to Offshore Facilities", Process Safety Progress, Vol. 35, No. 4 (2013), DOI 10.1002/ prs.11558; Heike Hoppe, "Goal-based Standards - A New Approach to the International Regulation of Ship Construction", WMU fournal of Maritime Affairs, (2005), Vol. 4, No. 2, 169-180.

99. Maher et al., "Paradigm Shift in the Regulatory Application of Safety Management Systems to Offshore Facilities".

100. Ole Andreas Engen, Janne Hagen and Jacob Kringen, "Tilsynsstrategi og HMS-regelverk i norsk petroleumsvirksomhet" [Revision strategy and HSE regulations in the Norwegian petroleum industry], Arbeidsdepartementet - Ministry of Labour, Oslo, (2013). 
101. Ibid.

102. "Introduction to IMO", IMO, accessed 14 April 2020. http://www.imo.org/en/About/Pages/ Default.aspx

103. Polar Code, IMO, Preamble, Para. 1.

104. Ibid., Ch. 8.

105. Ibid., Ch. 8.3.3.3.

106. Ibid., Part I-B, Ch. 9.1 and 9.2.

107. Solberg and Gudmestad, SARex3: evacuation to shore, survival and rescue.

108. Polar Code, IMO, Para. 8.2.3.3.

109. Maritimt Forum Nord SA, "SARINOR WP 4 og 5 Redning og overlevelse i kaldt klima" [Rescue and survival in cold climate], DNV GL, Report No. 2015-0931, Rev. 0.

110. Solberg and Gudmestad, SARex3: evacuation to shore, survival and rescue.

111. The interim guidelines for life-saving appliances and arrangements for ships operating in polar waters, IMO, Ch. 1.3.

112. Solberg and Gudmestad, SARex3: evacuation to shore, survival and rescue.

113. Maher et al., "Paradigm Shift in the Regulatory Application of Safety Management Systems to Offshore Facilities".

114. Polar Code, IMO, Ch. 1.5.

115. Preben Hempel Lindøe, Michael S. Baram and Ortwin Renn, Risk governance of offshore oil and gas operations (New York: Cambridge University Press, 2014).

116. Ove Njå and Øyvind Solberg, "Safety Considerations in Political Decisions: A Case Study of Changes to the Norwegian Aviation System", Review of Policy Research, Vol. 27(5) (2010), 595-619; Ove Njå and Kirsti Russel Vastveit, "Norske kommuners planlegging, gjennomføring og bruk av risiko- og sårbarhetsanalyse i forbindelse med samfunnssikkerhetsarbeidet" [Societal risk governance in municipalities is based on a weak regulatory regime and unclear professional competence], Stavanger: University of Stavanger (2016); Ove Njå et al., "Evaluering av risikovurderinger i Statens vegvesen. Beslutningsstøtte og læringsverktøy" [Evaluation of risk assessments in the Norwegian Public Roads Authority: Decision support and learning tool], Stavanger: International Research Institute of Stavanger (2013).

117. Geir Sverre Braut et al., "Risk images as basis for two categories of decisions", Risk management: An International fournal, Vol. 14 (2012), 60-76.

118. Nancy Leveson, Engineering a safer world: systems thinking applied to safety (Cambridge, Mass.: The MIT Press, 2011).

119. The Office of the Auditor General in Norway - Riksrevisjonen, "The Office of the Auditor General's investigation of the PSA's follow-up of health, safety and environment in the petroleum industry", The Office of the Auditor General in Norway, Document 3:6 (20182019), ISBN 978-82-8229-454-6.

120. Kathrine Pike et al., "15 Years of Shipping Accidents: A review for WWF", World Wildlife Fund, (2013).

121. Christian Kuran and Ove Njå, "Rule Bending in the Road Based Commercial Goods Transport Sector - A Systems Theory Approach", Paper presented at: The 3rd International Conference on Transport and Traffic Engineering, ICTTE, Belgrade, Serbia (2016); Ove Njå, Geir Sverre Braut and Ove Erik Vika, "Bending the Rules in the Commercial Goods Road Transport Sector", Procedia - Social and Behavioral Sciences, Vol. 48: 2336-2350 (2012).

122. Regulations on the construction, equipment and operation of passenger ships in the territorial waters surrounding Svalbard, NMA, p. 2.

123. Solberg, "Implications caused by SARex on the implementation of the IMO polar code on survival at sea".

124. Ibid. 
125. Regulations on the construction, equipment and operation of passenger ships in the territorial waters surrounding Svalbard, NMA.

126. The interim guidelines for life-saving appliances and arrangements for ships operating in polar waters, IMO, Ch. 1.1.

127. Solberg and Gudmestad, SARex3: evacuation to shore, survival and rescue.

128. The interim guidelines for life-saving appliances and arrangements for ships operating in polar waters, IMO.

129. Hendrik Schopmans, "Revisiting the Polar Code: Where Do We Stand?" The Arctic Institute, Center for Circumpolar Security Studies, Washington (11 June 2019); “Assembly, 31st session, 25 November to 4 December 2019”, IMO, accessed 14 April 2020. http://www.imo.org/en/ MediaCentre/MeetingSummaries/Assembly/Pages/Assembly-31st-session.aspx

130. PAME, "The increase in Arctic Shipping 2013-2019".

131. "Assembly, 31st session, 25 November to 4 December 2019", IMO.

132. "The Arctic Shipping Best Practice Information Forum", PAME.

133. William Scoresby, An account of the Arctic regions with a history and description of the northern whale-fishery. (Edinburgh: Printed for A. Constable \& co, 1820).

134. Ove Tobias Gudmestad and Johannes Alme, "Implementation of experience from the Arctic seal hunter expeditions during the late 19th and the 20th century", Ocean Engineering 111 (2016), 1-7, http://dx.doi.org/10.1016/j.oceaneng.2015.10.029

135. Solberg and Gudmestad, SARex3: evacuation to shore, survival and rescue; Marchenko et al., "Arctic Shipping and Risks: Emergency Categories and Response Capacities"; Andreassen et al., "Emergency Management in Maritime Mass Rescue Operations: The Case of the High Arctic".

136. Engen, Hagen and Kringen, "Tilsynsstrategi og HMS-regelverk i norsk petroleumsvirksomhet" [Revision strategy and HSE regulations in the Norwegian petroleum industry].

137. The Office of the Auditor General in Norway - Riksrevisjonen, "The Office of the Auditor General's investigation of the PSA's follow-up of health, safety and environment in the petroleum industry".

138. Regulations on port State control, NMA, No. 1458, 24 November 2014.

139. Regulations on the construction, equipment and operation of passenger ships in the territorial waters surrounding Svalbard, NMA, p. 2.

140. Ibid., Section 18, p. 14 .

141. Ibid.

142. Ibid., p. 14 . 